\title{
ADVANCES IN APPLE CULTURE WORLDWIDE ${ }^{1}$
}

\author{
TERENCE ROBINSON²
}

ABSTRACT - Over the last 60 years, planting densities for apple have increased as improved management systems have been developed. Dwarfing rootstocks have been the key to the dramatic changes in tree size, spacing and early production. The Malling series of dwarfing rootstocks (M.9 and M.26) have been the most important dwarfing rootstocks in the world but are poorly adapted in some areas of the world and they are susceptible to the bacterial disease fire blight and the soil disease complex, apple replant disease which limits their uses in some areas. Rootstock breeding programs in several parts of the world are developing improved rootstocks with resistance to fire blight, and replant disease, and improved cold hardiness and yield efficiency. A second important trend has been the increasing importance of new cultivars. New cultivars have provided opportunities for higher prices until they are over-produced. A new trend is the "variety club" in which variety owners manage the production and marketing of a new unique cultivar to bring higher prices to the growers and variety owners. This has led to many fruit growers being unable to plant or grow some new cultivars. Important rootstock and cultivar genes have been mapped and can be used in marker assisted selection of future rootstock and cultivar selections. Other important improvements in apple culture include the development of pre-formed trees, the development of minimal pruning strategies and limb angle bending which have also contributed to the dramatic changes in early production in the $2^{\text {nd }}-5^{\text {th }}$ years after planting. Studies on light interception and distribution have led to improved tree forms with better fruit quality. Simple pruning strategies and labor positioning platform machines have resulted in partial mechanization of pruning which has reduced management costs. Improved plant growth regulators for thinning and the development of a thinning prediction model based on tree carbohydrate balance have improved the ability to produce the optimum fruit size and crop load. Other new plant growth regulators have also allowed control of shoot growth, control of preharvest fruit drop and control of fruit softening in storage after harvest. As we look to the future, there will be continued incremental improvement in our understanding of plant physiology that will lead to continued incremental improvements in orchard management but there is likely to be dramatic changes in orchard production systems through genomics research and genetic engineering. A greater understanding of the genetic control of dwarfing, precocity, rooting, vegetative growth, flowering, fruit growth and disease resistance which will lead to new varieties and rootstocks which are less expensive to grow and manage.

Index terms: planting system, tree density, tree shape, rootstock, light interception, light distribution, feathered trees, tree training, limb angle, pruning, profitability, genome mapping.

\section{AVANÇOS NA POMICULTURA MUNDIAL}

RESUMO: Nos últimos 60 anos, as densidades de plantio para macieiras têm aumentado, uma vez que sistemas avançados de manejo têm sido desenvolvidos e a necessidade de produção precoce tem se tornado crítica. Porta-enxertos anões tem representado a chave para as dramáticas mudanças no tamanho das plantas, espaçamento e precocidade da produção. Em muitas partes do mundo, estacas Malling (M.9 e M.26) anãs têm representado a base para o adensamento do pomar, mas em outras áreas como no Brasil, porta-enxertos mais vigorosos tal como Marubakaido têm sido usados com um filtro M.9. Em anos recentes, o porta-enxerto Budagovsky 9 tem se tornado importante em áreas suscetíveis ao fogo bacteriano devido a sua tolerância à doença nos pomares. Novos porta-enxertos de Geneva ${ }^{\circledR}$ (G.11, G.41, G.202 and G.935), resistentes ao fogo bacteriano estão começando a ser plantados, oferecendo alta eficiência em produtividade e tolerância à doença. Além disso, eles são tolerantes às doenças da replanta, que vêm se tornando mundialmente, um problema sério em muitas áreas produtoras de maçã. Uma segunda tendência marcante tem sido a crescente importância do melhoramento para novas cultivares e porta-enxertos. Novas cultivares têm propiciado oportunidades de preços mais altos, até que elas sejam super-produzidas. Isso tem levado ao desenvolvimento de sociedades que controlam a produção e a comercialização, de forma a manter os preços altos. Essa situação tem levado a que muitos fruticultores se tornem incapazes de plantar algumas cultivares. Além do melhoramento

'Palestra Sinfruit 099 - Simpósio Internacional de Fruticultura - Avanços na Fruticultura (17 a 21 Outubro)

${ }^{2}$ Department of Horticulture New York State Agricultural Experiment Station Cornell University 630 W. North Street Geneva, NY 14456 USA. E-mail: terence-tlr1@cornell.edu 
tradicional, marcadores moleculares têm sido desenvolvidos de modo a propiciar a tecnologia de identificação 'fingerprinting' de variedades e porta enxertos. Genes importantes de porta-enxertos e cultivares têm sido mapeados e podem ser usados na seleção assistida por meio de marcadores moleculares, de futuras seleções de porta enxertos e cultivares. Outros avanços importantes na pomicultura incluem o desenvolvimento de árvores pré-formadas, desenvolvimento de estratégias de poda mínima e estudos fisiológicos de ângulo foliar que têm também contribuído para as mudanças dramáticas na produção precoce entre o segundo e o quinto ano após o plantio. Estudos sobre a interceptação e distribuição da luz têm conduzido a estratégias práticas de poda e aprimoramento da arquitetura das plantas, propiciando frutos de melhor qualidade. Estratégias simples de poda e máquinas têm resultado em mecanização parcial ou completa da poda, com redução dos custos de manejo. Novos reguladores de crescimento para desbaste e desenvolvimento de modelos de desbaste baseados no balance de carboidratos da planta têm melhorado a habilidade da planta apresentar alta produtividade, com a geração de frutos graúdos. Outros novos reguladores de crescimento têm também permitido controlar o crescimento dos ramos, controlar a queda pré-colheita dos frutos e controlar o amolecimento dos frutos no armazenamento pós-colheita. No futuro, haverá melhoramento continuado da nossa compreensão da fisiologia da planta que conduzirá a um aprimoramento do manejo dos pomares, mas é provável que haja grandes mudanças nos sistemas de produção e manejo dos pomares mediante pesquisas em genômica e engenharia genética. Deverão estar envolvidos conhecimentos no âmbito do controle genético do nanismo, precocidade, enraizamento, desenvolvimento vegetativo, florescimento, frutificação e resistência a doenças, que levarão à obtenção de novas variedades-copa e porta-enxertos, com redução do custo de manejo e produção. Será também possível que uma vez identificados os genes que controlam o nanismo, a precocidade e o enraizamento, possa haver a incorporação de tais características, às novas variedades-copa, eliminando, portanto, a necessidade de porta-enxertos.

Termos para indexação: sistema de plantio, porta-enxertos, luz, práticas culturais, genômica.

\section{INTRODUCTION}

Apple culture around the world has undergone radical changes over the last 60 years moving from traditional production systems using widely-spaced large trees to more intensive production systems using closely-spaced smaller trees. In the early 1900's, most commercial apple orchards utilized trees on seedling rootstocks and had large globular shaped tree canopies that allowed cattle to graze under the trees. Most orchards were planted at a density of 70-100 trees/ha. Today, tree densities of modern apple orchards range from 1,000 to 6,000 trees/ha with some systems using densities up to 10,000 trees/ ha (Robinson, 2003). Over the last 60 years, numerous planting systems for modern orchards have been developed. The best of these planting systems have similarities and are based on the same underlying principles. They include dwarfing rootstocks, high planting densities, renewal pruning, and growth regulators which result in high early yields, high sustained yields and excellent fruit quality.

\section{DWARFING ROOTSTOCKS}

Dwarfing rootstocks have been the key to the dramatic changes in tree size, spacing and early production. In the 1920's, Ronald Hatton of East Malling
Research Station in the United Kingdom collected clonal dwarfing rootstocks from all over Europe, categorized and then released the Malling series of apple rootstocks (Malling1 to Malling 24) which spurred the commercial development of orchard systems based on smaller trees (WALKER, 1980). A planned breeding program between the John Innes Institute at Merton England and the East Malling research station to produce wooly apple aphid resistant stocks resulted in the Merton Immune (MI) series and later the Malling-Merton Series (MM.101-115). Rootstocks from these programs have now become the primary rootstocks used throughout the world (WERTHEIM, 1998). In the 1930 's, planting systems based on smaller trees and clonal rootstocks were developed in Holland and England (WERTHEIM, 1981). The tree canopy was lowered to only $50 \mathrm{~cm}$ above the ground which no longer allowed animal grazing in apple orchards. The tree height was reduced from $6-8 \mathrm{~m}$ to $4-5 \mathrm{~m}$ and tree density was increased from 70-100 trees/ha to 250-350 trees/ha. In the 1950's and 60's, systems utilizing semi-dwarf rootstocks at densities from 300-500 trees/ha were developed. These tree systems had earlier production induced by the semidwarfing rootstocks, easier management due to the smaller trees and higher orchard productivity. In the early 1970 's, systems utilizing the fully dwarf M.9 rootstock were developed at densities of 1,000-2,000 
trees/ha. Since then, there has been a continual march toward higher and higher tree densities in most apple growing districts of the world and M.9 rootstock has become the dominant rootstock in the world.

Research on apple rootstocks has shown that the rootstock has a large effect on tree precocity (flowering and cropping in the early years), as well as productivity. Rootstock also determines tree size which determines labor efficiency. Dwarfing stocks allow high tree densities to be maintained in their allotted space with less expense as the orchard matures. Rootstocks also influence the partitioning of the trees resources between vegetative growth and cropping. Other rootstock characteristics that have become important include improved fruit size, tolerance to diseases such as fire blight, phytothphora, apple replant disease and crowngall; tolerance to insects such as woolly apple aphid (WAA), and tolerance to abiotic stresses such as drought, water excess, spring frost and winter cold tolerance.

Most successful high density apple plantings are planted with dwarfing rootstocks such as M.9, M.26 or B.9 rootstocks. In recent years, Budagovsky 9 has become an important dwarfing rootstocks due to its tolerance or the bacterial disease fire blight. Although it is possible to plant high density orchards on semi-dwarf rootstocks such as M.7, or semi-vigorous rootstocks such as MM.111, MM.106, M.793, or Marubakaido their lack of precocity is a serious limitation to this approach. In addition, their inherent vigor makes management of the mature high density orchard much more difficult. In some areas of the world such as Brazil vigorous rootstocks such as Marubakaido have been used with an M.9 interstem. This approach has given intermediate vigor but often as the trees age excessive vigor becomes a problem.

The limitations of the Malling series of rootstocks from England include lack of winter hardiness, lack of resistance to Phytophthora root rot, susceptibility to fire blight bacterial disease, burrknots, poor anchorage, root suckers, sensitivity to apple replant disease and brittle graft unions. To overcome these deficiencies, planned breeding programs have been carried out in various parts of the world including the United States (CG, MAC, OAR, Arkansas and Minnesota series), Canada (KSC, Ottawa and Vineland series), the United Kingdom (MI, MM and AR series), Germany (J.9 and Pillnitzer-Supporter series), Sweden (Alnarp, Bemali and BM series), Russia (Budagovsky series), Poland (P series), the Czech Republic (JT-E series), Israel (MH series), Romania (Voinesti series) and Japan (JM series). In the last decade, programs to improve existing rootstocks through genetic engineering have been initiated in the USA (Cornell University-fire blight resistance), Russia (herbicide resistance), France (improved rooting) and Sweden (rooting gene). All of the rootstock breeding programs have focused on the horticulturally important traits of productivity, dwarfing and precocity, but certain programs have also emphasized other characteristics such as disease resistance, insect resistance, propagability or stress tolerance. New fire blight resistant and replant disease resistant apple rootstocks from Geneva ${ }^{\circledR}$ (G.11, G.41, G.202, G.935 and G.969) are beginning to be planted in many countries. In addition to disease resistance they offer high yield efficiency and dwarfing. Over the next 20 years, it is likely that improved rootstocks from these breeding programs will replace the Malling rootstocks.

\section{INTENSIVE PLANTING SYSTEMS}

Light interception. In the 1960's studies of canopy light interception and how to optimize it played a critical role in new orchard system development. Cain (1970) introduced the idea that orchard light interception should be considered over the lifetime of the orchard. He found that the mean lifetime fraction of land covered by tree canopy increased as tree size decreased and tree planting density increased. A meaningful variable of orchard performance would be mean lifetime fraction of light intercepted, but few studies have calculated such an index. The realization that significant land and light resources were wasted in the early life of an orchard has encouraged the planting of higher and higher tree densities. This has resulted in greater early yield and greater lifetime light interception. In a spacing trial, Palmer and Jackson (1974) reported that with densities ranging from 853 to 3746 trees/ha, yield and light interception were approximately linearly related. Light interception was closely related to LAI, not just trees per acre. Mathematical models of light interception have been constructed to estimate light interception from different canopy shapes and planting configurations (Jackson, 1981; Palmer, 1981).

These studies and others led to the underlying principle that mature yield of fruit orchards, regardless of planting density or pruning system, is related to total light interception (JACKSON, 1980; PALMER, 1989). Although early yields appear to be largely a function of tree density and rootstock, mature yields can differ substantially depending on light interception. Light interception is largely a function of tree shape and tree arrangement.

Orchard canopies, unlike those of other crops, are of necessity discontinuous due to the alleyways 
maintained between rows for orchard machinery which results in a large proportion of the land area not covered by trees. This results in low values for leaf area index (LAI) and total light interception for orchard canopies when compared to other crops. Because of the tractor alleys used for orchard management, light interception is more strongly influenced by tree height to clear alley ratios and tree numbers per hectare than canopy density.

From the mid 1970's to the late 1980's, there was a strong move toward pedestrian orchards (small trees where all orchard management operations could be done from the ground). In many cases, the decrease in tree size was not accompanied by a sufficient reduction in tractor alley width and tree height was kept too low for high light interception. As a consequence, many pedestrian orchards had relatively low mature yields. Since there is a relationship between tree height and between row spacing on total light interception, the problem of low yield with short stature trees was solved by reducing row widths or increasing tree heights (ROBINSON et al., 1991). For optimum light interception, the ratio of tree height to row spacing should be 0.8-0.9. Many of the pedestrian orchards of the 1980's which had short trees and utilized existing wide machinery, had height to row spacing ratios of 0.5 or less. Using the optimum ratio, typical row spacings used in high density orchards of $3.0-3.5 \mathrm{~m}$ should have mature tree heights of 2.7-3.2m. Failures of mature high density orchards to produce expected yields at maturity can usually be traced to trees not intercepting enough light. Where growers desire short stature trees $(<2.5 \mathrm{~m}$ tall $)$ which can be picked from the ground they should reduce tractor alleys to $2.8 \mathrm{~m}$ or less.

Intensive bed systems were studied by Palmer and Jackson (1977) and multi-row systems by Wertheim (1986). Palmer (1988) has shown that bed systems can intercept up to $80 \%$ of PAR from the end of June until October and yield 78 tons/ ha in the third year. Although they have high light interception and high yields they have generally not been adopted widely since they are not compatible with conventional orchard machinery. Single row arrangements continue to be the most successful.

Tree planting density. In the early years of an orchard's life, light interception by the canopy is low which limits potential yield. A major objective during the first few years is to develop the full canopy as quickly as possible. With tree densities below 500 trees/ha this can take 7-12 years. With high tree densities between 2,500 and 3,000 trees/ha, typical of modern high density orchards, full canopy can be achieved by the end of the third or fourth season.
With the very high tree densities of the super spindle system $(>5,000)$ canopy closure can be achieved by the end of the first year.

Data from several studies show that yields are related to tree density with the highest tree density producing the highest cumulative yield. With modern high density orchards, a small but significant yield is expected during the second growing season of the orchard. Substantial yields are expected in the third year and mature yields are expected by year 5 . In contrast, traditional low density systems on vigorous rootstocks begin production around year 6 or 7 and do not reach mature yields until year 10-12. In the early years the relationship of tree density and cumulative yield is essentially linear but rapidly becomes curvilinear in later years. Our data from NY shows that by year 5 the relationship of tree density and cumulative yield is only slightly curvilinear but as the orchard ages the relationship of cumulative yield and tree density becomes strongly curvilinear by the end of year 9 . However, even after 22 years we found a positive curvilinear relationship between tree density and cumulative yield. Thus, although low density systems, once fully grown, can achieve similar mature yields as high density systems the early advantage of the high density systems results in the cumulative yield of the high density systems being greater than the low density systems (ROBINSON, 2000).

The curvilinear relationship of planting density and cumulative yield over the life of an orchard is typical of the economic law of diminishing returns which states that additional increases in an input factor (trees per hectare) produces a smaller and smaller increase in an output factor (cumulative yield per hectare). At the high end of this curvilinear relationship additional increases in trees density will not produce enough extra yield to pay for the additional costs incurred to purchase and plant the extra trees. (Weber, 2000). Thus the optimum tree density in any apple producing area becomes an economic question. The law of diminishing returns dictates that the optimum density will be less than the density with the highest yield.

Our latest economic analysis under New York economic conditions has indicated that densities between 2,500-3,000 trees/ha are more profitable than lower or higher densities (DeMARREE et al., 2003, ROBINSON et al., 2007). The results of our economic analysis may not be valid for other parts of the world with different fruit, tree and land prices. Nevertheless, for most fruit growing areas of the world it is it is our opinion that tree densities up to about 3,000 trees per hectare will result in greater profitability and manageable levels of risk. Above 
this density, it appears, that despite producing greater cumulative yields, profitability is only slightly greater and in some cases less than lower densities; however, the economic risk is increased significantly with very high density orchards. Despite some latitude in planting densities to account for soil vigor, scion vigor and climate, growers should remember that to obtain high early yields high tree densities are essential with the optimum being $\sim 3,000$ trees/ha.

Light distribution. In the 1960's studies of light distribution in apple canopies showed that with large round-crown trees, a large central core of the canopy receives very low light intensities (6-30\% of full sunlight) and produced relatively few fruits (LOONEY, 1968). The exterior quarter of the canopy had a small percentage of the total leaf area yet had a large shading effect on the rest of the tree where the major portion of the leaf surface was located. Heinicke (1963) proposed that $30 \%$ of full sun serve as a lower limit of the desired light levels in apple canopies and Jackson (1970) found that this was generally within $1 \mathrm{~m}$ of the canopy exterior. A number of studies have linked fruit quality with light exposure of the fruiting site (JACKSON, 1970; ROBINSON et al., 1983; WÜNSCHE et al., 1996). In general shaded areas of the canopy produce smaller fruit size, poorer fruit color, less return bloom and weak fruiting spurs.

Heinicke (1964) found that as tree size decreased the heavily shaded area within the tree decreased. Robinson et al., (1991) found that the poor illumination of the large conic shaped trees was due to the excessive depth of the canopy while small conic shaped trees could also have poor illumination if the denseness of the branches and foliage within the small canopy was high. Sansavini et al., (1981) found under vigorous growth conditions that light levels in the lower part of the canopy of a slender spindle multi-row system were lower than in a medium density Palmette hedgerow. With vigorous growth conditions, the small gaps between branches of dwarf trees can be closed very quickly in the season leading to poor fruit color and quality if the trees are not summer pruned (CORELLI; SANSAVINI, 1989).

In general, studies on light distribution have shown that tall narrow canopies such as the Tall Spindle, Super Spindle, Vertical axis, and Palmette trellis have good light distribution. As the trees age it becomes critical to keep the top of the tree is kept more narrow than the bottom of the tree. For conic systems like Tall Spindle and the Vertical axis, maintaining a conic shape as the trees age is critical to maintaining good light exposure, fruiting and fruit quality in the bottom of the tree.
The key objectives for a new orchard continue to be maximizing yield in the early years and still effectively produce large yields of high quality fruit after the trees are mature. The Tall Spindle management system accomplishes these objectives by combining high tree planting densities, highly feathered trees that have many small branches instead of a few large branches, minimal pruning at planting or during the first 3 years, branch angle management by tying down all of the feathers at planting to induce cropping and prevent the development of strong scaffold branches that cause difficulty in tree management in later years, and branch caliper management by the systematic removal of large branches to keep the tree manageable. Since large branches contribute to the development of large trees the Tall Spindle trees which have no large scaffold branches remain small. Our most recent economic analysis shows the optimum economic density for NY is the 2,5003,300 trees/ha of the tall spindle system. Thus it is the recommended system for apple growers.

\section{FEATHERED TREES}

Before 1970, almost all maiden trees produced by nurseries were single shoot whips. These trees were headed severely at planting in the orchard and then grown vigorously for several years to develop a large and strong branch framework to support future large crops. With the development of high density orchard systems, several researchers began to study alternative approaches to tree management that involved less pruning. The larger the initial caliper of the tree at planting the greater the growth and yield in the first 4-5 years. The greater the number of feathers at planting the greater the yield especially in the second and third year (FERREE et al., 1987; ROBINSON; STILES, 1991, VAN OOSTEN, 1978). The severity of pruning of newly planted trees also came into question in the early 1970's. Lespinasse (1980) showed that leaving the tree unpruned at planting resulted in greater total growth and weaker side branches. This gave a more balanced tree. The use of feathered trees combined with minimal pruning resulted in a significant improvement in growth and yield over the first 5 years. More recently, the internal quality of nursery trees has become important. Cheng and Fuchigama (2002) found that the level of nitrogen reserves is an important measure of the trees ability to grow after transplanting from the nursery to the orchard. Secondarily, carbohydrate reserves are important since they provide energy and building blocks for the new growth in the spring.

As the benefits of highly feathered trees were 
discovered, it became necessary to develop nursery management techniques to stimulate lateral branch development. This led to the development of the 2 year tree branched tree, the 2 year "knip" tree, leaf removal techniques, fertigation, the use of synthetic cytokinnin foliar sprays (benzyl adenenine) and foliar sprays of the auxin inhibitor (cyclanalide) to induce branching. As these practices have been implemented by nurseries, the quality (caliper and number of feathers) of nursery trees has improved considerably over the last 20 years. Currently, the ideal tree for high density plantings should have a minimum diameter of $15 \mathrm{~mm}$ and $10-12$ well positioned feathers with a maximum length of $40 \mathrm{~cm}$ and starting at a minimum height to $80 \mathrm{~cm}$ from the soil (BALKHOVEN-BAART, et al., 2000; WEIS, 2004). An exception to this standard is for planting in the super high density systems (Super Spindle or V Super Spindle), where the cost of such high quality trees makes these systems less profitable (Weber, 2000). With these systems, less expensive trees are needed and either sleeping eye budded rootstocks or medium caliper trees with many short dards are preferred. With these systems, the trees are planted so close together $(50-60 \mathrm{~cm})$ in the orchard that very little additional lateral extension growth is needed after planting to fill the space.

\section{LIMB ANGLE}

Branch angle of fruit trees, has been manipulated for many centuries in small gardens; however, most orchards prior to 1960 were developed in a free form with little branch manipulation. With the development of the central leader and slender spindle planting systems in the late 1960's, branch manipulation became an important part of early tree management (WERTHEIM, 1968). With the central leader systems, branches were spread down with wooden spreaders to $20-40^{\circ}$ above horizontal in the third or the fourth year. With the slender spindle system, branches were usually tied down to horizontal or below horizontal in the second year. Lespinasse (1977) studied branch angle and its effect on flowering, cropping and fruit size. Branch angles above $45^{\circ}$ produced vigorous growth and little flowering. Angles from $45^{\circ}$ down to horizontal produced less growth, heavy flowering and high fruit size and quality. Angles below horizontal produced almost no terminal growth but often had small spurs and small fruit size. Thus, manipulation of branch angle became an important tool in managing high density orchards. With medium density orchards, lower tier branches were trained to an angle slightly above horizontal to allow continued extension growth of the branch. However, with high tree densities, branches were trained horizontal to stop further extension growth. With the very high planting densities of the Tall Spindle (Robinson, 2006) or the Solaxe (LESPINASSE, 1996), branches are tied below the horizontal to induce early cropping and prevent further extension of lateral branches. By manipulating branch angle, fruit growers have been able to manage tree growth at a wide variety of planting densities.

\section{PRUNING}

Pruning of fruit trees has been studied for centuries. Most pruning systems utilized heading cuts. With the Central Leader system, heading cuts of the leader were used to develop tiers of branches. The upper tiers of branches were designed to be permanent, but as the tree aged, these permanent branches became large in diameter and shaded the lower portions of the tree. Over the last 30 years, a number of studies have focused on the natural growth of the tree to develop improved pruning approaches. Lespinasse (1977) studied the natural growth of different tree types and developed the concept of renewal pruning. He developed the Vertical Axis system to take advantage of the natural growth habit of the tree and to minimize the shading problem of permanent upper tier branches. The system is designed around two concepts: 1) not heading the leader during the development years, thereby, growing the tree tall very quickly and 2) preventing the development of strong upper tiers of scaffolds by removing and renewing back to the trunk of any upper branches that get too large and begin to shade the bottom. The height of the tree is limited by fruiting and the dwarfing rootstock.

Pruning studies by Robinson (1987) on restructuring overgrown Central Leader trees, showed that the best way to keep the top of Central Leader trees narrow while maintaining a balance between vegetative growth and cropping was to remove whole limbs in the top of the tree. Once branches in the top of the tree grew too long they should be removed rather than shortened back and kept as permanent scaffold branches.

Good light distribution and good fruit quality can be maintained as trees age if the top of the tree is kept more narrow than the bottom of the tree and if there is a good balance between vegetative growth and cropping. For the tall spindle system, maintaining a conic shape as the trees age is critical to maintaining good light exposure, fruiting and fruit quality in the bottom of the tree. A successful approach to managing the tops of trees in the Tall Spindle is to an- 
nually remove 1-2 large upper branches completely. To assure the development of a replacement branch, the large branch should be removed with an angled or beveled cut so that a small stub of the lower portion of the branch remains. From this stub a flat weak replacement branch often grows. If these are left unheaded they will naturally bend down with crop. If this is repeated annually for 3-4 years, the top of the tree can be composed completely of young fruitful branches. The younger branches are naturally shorter than the bottom branches, thus maintaining the conic shape of the tree. This strategy was much more successful than shortening back upper tier limbs to maintain the conic shape. This strategy has been employed with most high density systems including vertical axis (LESPINASSE, 1980), slender spindle, Tall spindle (Robinson et al., 2006), Super spindle (WEBER, 2000) and Y-trellis (ROBINSON et al., 1993) to maintain good light distribution over the life of the tree.

\section{NEW CULTIVARS}

Since the mid 1980's a series of new cultivars have been introduced to the world apple market which has created a dynamic marketplace for new cultivars. Some cultivars were quickly discarded but others such as Granny Smith, Gala, Jonagold, Empire, Fuji and Pink Lady have become important world varieties. In most cases the fruit price was very high when the variety was introduced but as production increased the price dropped. In an effort to keep the price of new cultivars high the concept of a "variety club" was developed whereby production could be limited and money for marketing programs could be generated by the club members.. This involved organizing a club of growers who would produce only a pre-determined volume of fruit and they would each contribute money to promote and market the cultivar. The first successful club was with Pink Lady from Australia but it was followed by clubs of 3 cultivars from New Zealand, Pacific Rose, Pacific Beauty and Jazz. Currently there are more than 10 variety clubs operating in Europe and about 7 clubs operating in North America (BROWN; MALONEY, 2009). These include 'Sweet Tango', 'Ambrosia' 'Pinata' 'Cameo', 'Jazz', 'Sonya', 'Pacific Rose' and 'Jazz'. Variety club owners use patents, and trademarks to protect their variety from planting by unauthorized growers. It is common for a variety to have different patent name and trademark name and some varieties are marketed under several different names depending on region in which they are grown.

Recently a new variety club was organized in NY State to grow and promote two new cultivars from
Cornell University (NY1 and NY2). Similarly a new cultivar from Washington State University (WA2) is being developed for production within a club.

\section{MECHANIZATION}

As the cost of hand labor has increased, apple growers have begun efforts to reduce labor costs through partial mechanization of orchard tasks. The effort is proceeding along 2 fronts. Motorized platforms to position human workers for greater efficiency and robotic machines.

Motorized platforms are in common use in some parts of Europe but recently have become common in the USA. In the last 5 years, research and extension projects have been conducted to adapt motorized platforms to existing high density orchard for the operations of harvest, hand thinning, pruning and tree training. The main advantage of worker positioning platform is the time and labor savings of not having to carrying ladders through the orchard, nor climb up and down to perform various jobs. In addition there are two other potential advantages to using an orchard platform. 1) Encouraging the same work speed of an entire work crew, with the intention of increasing productivity and preventing over/under pruning or hand thinning of trees that can happen when the rate of speed down the row is NOT controlled (as with ladders). 2) Human physical effort is reduced (if managed well), allowing a wider labor pool, people who could not climb up and down a ladder repeatedly during the day may now be able to perform this work.

Miranda et al., (2010) studied labor efficiency with a platform and showed that dormant pruning time was reduced from 1.26 minutes/tree to $0.92 \mathrm{~min}$ utes/tree when the same workers utilized a platform and pruned mature Gala and McIntosh's tall spindle apple trees in Wolcott, NY. The pruning platforms reduced labor costs by about 27-30 percent. There was little difference in labor efficiency between the types of platform used. An economic analysis of investment in a platform, showed that the use of orchard platforms could save \$102/acre, \$140/acre and $\$ 45 /$ acre for dormant pruning, hand thinning and trellis wire installation, respectively.

Platform assisted harvest has not been very successful in the US due to greater bruising with the mechanized bin fillers than with the current bucket and ladder hand harvest system. The gains in efficiency have also been modest. Greater success has been achieved with the use of platforms to position workers for pruning, hand thinning and tree training. Significant acreage is currently managed with self 
steering motorized platforms for dormant pruning, hand thinning and tree training.

A long-term effort is underway in the USA to utilize robotic technology in orchard tasks to reduce hand labor. This effort is based on the phenomenal advances in computer technology seen in the last 10 years. It is now possible with machine vision for computers to identify fruits, branches, trunks and trellis posts and wire. Inexpensive powerful computers and advances in robotics now make possible such field robots. In the last 3 years research has been conducted on machine vision to locate fruits and branches for possible mechanical harvest. This effort will require many years due to the extreme complexity of identifying the fruit location, detaching the fruit without bruising, and transporting the fruit to the bin without bruising. A more near-term possibility is the use of robots to prune apple trees. This will require simple, single dimensional trees with no permanent branches such as the Tall spindle or the super spindle. It will also require machine vision to locate branches and map a pruning path and simple pruning rules. The Tall Spindle could be adapted to such a system since the pruning could be simplified to the single rule of removing any branch that is larger than $2 \mathrm{~cm}$ in diameter.

\section{PLANT GROWTH REGULATORS}

Apple production has utilized plant growth regulators for more than 50 years. The first use was to cause fruit thinning. In the 1940 's caustic chemicals were discoed which caused the abscission of a portion of the flowers or fruits. These chemicals were followed by the discovery of synthetic plant hormones which selectively caused fruit abscission. The synthetic auxin Napthaleneacetic acid (NAA) has become an essential tool in chemical fruit thinning of apples. Later, other plant growth regulators were discovered which have become important in fruit thinning. These include ethephon (ethylene releasing chemical) benzyl adenine (cytokinin).

Fruit thinning is the single most important yet difficult management strategy that determines the annual profitability of apple orchards. Despite over 40 years of experience with chemical thinning, it remains an unpredictable part of apple production with large variations from year to year and within years due to weather. Although many factors affect apple thinning response, it appears that periods of carbohydrate surplus or deficit as estimated by our carbohydrate model are important to the response to post-bloom chemical thinners. We have developed a computer model to estimate tree carbohydrate status based on temperature and sunlight conditions. Stud- ies over the last 10 years in New York state have shown that periods of carbohydrate deficits are associated with periods of high chemical thinner efficacy while periods of carbohydrate surplus are associated with poor chemical thinner efficacy. It appears that the greatest risk of over-thinning occurs at the 10 $20 \mathrm{~mm}$ fruit diameter stage since this is when fruitlets are growing rapidly with a high demand for carbon and any sustained shortage of carbon appears to result in abscission of the weakest fruit. For unknown reasons, when fruit are larger than $20 \mathrm{~mm}$ they are less susceptible to chemical thinners. At petal fall, the risk of over-thinning is low since fruits are growing slowly and shortages of carbon appear to result in moderate thinning. We have constructed a family of predictive curves which allow prediction of thinning results from petal fall to 21 days after petalfall. Over the next two years, we are planning to construct a web-based version of the carbohydrate model that growers and consultants could use to predict thinning response in real time.

Plant growth regulators are also used for induction of lateral branching in the nursery and the orchard (Promalin, Maxcel and Tiberon), to control shoot growth (Regalis, Apogee, prohexadione-Ca), prevent preharvest drop (NAA, Retain, Harvista) and to stop fruit softening in storage (Smart Fresh). Each of these uses of plant growth regulators has improved the ability of growers to produce and deliver high fruit quality to the consumer.

\section{GENOMICS}

The significant advances in apple orchard management over the last 60 years have primarily been achieved by traditional breeding and selection, understanding plant physiology and field experimentation. Until now genetics and genomics have had little impact on orchard management; however, in the future genomics may play a much greater role. Work over the last 20 years has identified many important, useful genes in apple and culminated last year with the complete sequencing of the genome of apple. Important genes that have been mapped include resistance genes to fire blight and scab, dwarfing genes, rooting genes, and genes in the ethylene/ripening pathway. Over the next few years we expect to understand the genetic control of many tree and fruit developmental genes and disease resistant genes.

\section{FUTURE ADVANCES}

As we look to the future, it is certain that we will see continued incremental improvement in our 
understanding of plant physiology that will lead to continued incremental improvements in orchard management. However, it is possible we will see dramatic changes in the fruit production system through genetic engineering.

Incrementally we will see increased understanding of the mechanisms of dwarfing, rooting, precocity, flowering, fruit growth, maturation and disease resistance. This will lead to new improved rootstocks and cultivars with improved dwarfing and productivity in apple and significantly improved disease resistance. Further research will lead to improved canopy and crop load management strategies with greater emphasis on quality, fruit size and environmental impacts. It will also result in improved methods of managing canopy vigor to achieve calm trees with a good balance between vegetative growth and cropping.

The current work on genomics will lead to the identification of the major genes that control important rootstock and cultivar characteristics such as dwarfing, rooting precocity, flowering, fruit quality, and disease resistance and then incorporating those genes directly into new varieties via genetic engineering. This may lead to the elimination of the need for rootstocks. If the heterozygosity of Malus $x$ domestica could be overcome through haploid seeds. This would allow a seed based system of plant propagation which would dramatically change plant cost and would allow orchard planting densities similar to cereal crops.

With either the incremental improvement scenario or the dramatic improvement scenario, we need a greater understanding of the genetic control of vegetative growth, flowering and fruit growth as well as greater understanding of the physiology of pruning and thinning. The current genomics research worldwide will improve our understanding of plant growth and development and will likely lead to significant advances in high density orchard systems. Even if rootstocks are not eliminated, studies on rootstock genes, physiology of roots, rootstock/scion and the influence of rootstock on scion performance will lead to improved rootstocks that are more adapted to biotic and abiotic stresses.

\section{CONCLUSIONS}

Over the last 60 years, there have been dramatic changes in high density apple growing that have been stimulated by the development of dwarfing rootstocks and high density management systems. Improved management strategies such as feathered trees, development of minimal pruning strategies, renewal pruning and physiological studies of limb angle have also contributed to the dramatic changes in tree density. Other studies on light interception and distribution, have led to practical pruning strategies and improved tree forms. However, economic considerations have halted the march toward higher and higher tree densities. The need for clonally propagated rootstocks makes trees too expensive to allow densities as high as management technology allows. The future may have only small incremental improvements compared to what has been achieved over the last 60 years. However, continued improvements in orchard management will result in improved fruit quality and efforts to reduce hand labor will reduce the cost of production per kilo of fruit.

\section{REFERENCES}

BALKHOVEN-BAART, J.M.T.; WAGENMAKERS, P.S.; BOOTSMA, J.H.; GROOT, M.J.; WERTHEIM S.J. Developments in Dutch apple plantings. Acta Horticulturae, The Hague, v.513, p.261-269., 2000.

BROWN, S.K.; MALONEY, K.E. Making sense of new apple varieties, trademarks and clubs: current status. New York Fruit Quarterly, New York, v.17, n.3, p.9-12, 2009..

CAIN, J.C. Optimum tree density for apple orchards. HortScience, Alexandria, v.5, p. 232-234, 1970.

CHENG, L.; FUCHIGAMI, L.H. Growth of young apple trees in relation to reserve nitrogen and carbohydrates. Tree Physiology, Oxford, v.22, p.12971303, 2002.

CORELLI, L.; SANSAVINI, S. Light management and photosynthesis related to planting density and canopy management in apple. Acta Horticulturae, The Hague, v.243, p.159-174, 1989.

DEMARREE, A.; ROBINSON, T.L.; HOYING, S.A.. Economics and the orchard system decision. Compact Fruit Tree, Tasmânia, n.36, p.42-49, 2003. Special issue

FERREE, D.C.; RHODUS, W.T. Early performance and economic value of feathered apple trees on semi standard rootstocks. Journal of the American Society Horticultural Science, Alexandria, v.112, p. 906-909, 1987.

HEINICKE, D.R.. The micro-climate of fruit trees. II. Foliage and light distribution patterns in apple trees. Proceedings of the American Society Horticultural Science, Alexandria, v.83, p.1-11, 1963. 
HEINICKE, D.R. The micro-climate of fruit trees. III. The effect of tree size on light penetration and leaf area in 'Red Delicious' apple trees. Proceedings of the American Society Horticultural Science, Alexandria, v.85, p.33-41, 1964.

JACKSON, J.E. Aspects of light climate within apple orchards. Journal of Applied Ecology, Oxford, v.7, p. 207-216, 1970.

JACKSON, J.E. Light interception and utilization by orchard systems. Horticultural Reviews, New York, v.2, p.208-267, 1980.

JACKSON, J.E. Theory of light interception by orchards and a modeling approach to optimizing orchard design. Acta Horticulturae, The Hague, v.114, p. 69-79, 1981.

LESPINASSE, J.M. La conduite du pommier: I. types de fructification. Incidence sur la conduite de l'arbre. Paris: INVUFLEC, 1977. 80p.

LESPINASSE, J.M. La conduite du pommier: II. l'axe vertical. La rénovation de verges. Paris: I NVUFLEC, 1980. 120p.

LESPINASSE, J. M. Apple orchard management practices in France: From the vertical axis to the SolAxe. Compact Fruit Tree, Tâsmania, v.29, p.83-88, 1996.

LOONEY, N.E. Light regimes within standard size apple trees as determined spectrophotometrically. Proceedings of the American Society Horticultural Science, Alexandria, v.93, p.1-6, 1968.

MIRANDA-SAZO, M., DEMARREE, A. AND ROBINSON, T. The platform factor: Labor positioning machines producing good results for NY apple industry. New York Fruit Quarterly, New York, v.18, n.2, p.5-9, 2010.

OSTERREICHER, J. Achieving a balance of growth and cropping: Practical considerations of how to obtain a calm tree. Compact Fruit Tree, Tâsmania, v.37, p.19-20, 2004.

PALMER, J.W. Computed effects of spacing on light interception and distribution within hedgerow trees in relation to productivity. Acta Horticulturae, The Hague, v.114, p. 80-88, 1981.
PALMER, J.W. Canopy manipulation for optimum utilization of light. In: WRIGHT, C.J. (Ed.). Manipulation of fruiting. London: Butterworths, 1989. p.245-262.

PALMER, J.W.; JACKSON, J.E. 1974. Effects of tree population and variations in spacing within and between rows of 'Golden Delicious' on M.9. Maidstone: East Malling Research Station, 1973. p. 66-68.

PALMER, J.W.; JACKSON, J.E. Seasonal light interception and canopy development in hedgerow and bed system apple orchards. Journal of Applied Ecology, Oxford, v.14, p.539-549, 1977.

ROBINSON, T.L. V-shaped apple planting systems. Acta Horticulturae, The Hague, v.513, p.337-347, 2000.

ROBINSON, T.L. Apple orchard systems. In: FERREE, D.C.; WARRINGTON, I.J. (Ed.). Apples: physiology, production and uses. Wallingford: CABI Publishing, 2003.

ROBINSON, T.L. The palmette leader tree. Lewiston: Maine State Pomological Society, 1987.

ROBINSON, T.L.; LAKSO, A.N. Bases of yield and production efficiency in apple orchard systems. Journal of the American Society Horticultural Science, Alexandria, v.116, p. 188-194, 1991.

ROBINSON, T.L.; STILES, W.C. Maximizing the performance of newly planted apple trees. Proceedings of the New York State Horticultural Society, Tallahassee, v.136, p.199-205, 1991.

ROBINSON, T.L.; SEELEY, E.J.; BARRITT, B.H. Effect of light environment and spur age on 'Delicious' apple fruit size and quality. Journal of the American Society Horticultural Science, Alexandria, v.108, p.855-861, 1983.

ROBINSON, T.L.; LAKSO, A.N.; REN, Z. Modifying apple tree canopies for improved production efficiency. HortScience, Alexandria, v.26, p.10051012, 1991,

ROBINSON, T.L.; WÜNSCHE, J.; LAKSO, A.N. The influence of orchard system and pruning severity on yield, light interception, conversion efficiency, partitioning index and leaf area index. Acta Horticulturae, The Hague, v.349, p.123-127, 1993. 
ROBINSON. T.L.; HOYING, S.A.; REGINATO, G.L. The Tall Spindle apple planting system. New York Fruit Quarterly, New York, v.14, n .2, p.2128, 2006.

ROBINSON, T.L., DEMARREE, A.M.; HOYING, S.A. An economic comparison of five high density apple planting systems. Acta Horticulturae, The Hague, v.32, p.481-490, 2007.

SANSAVINI, S.; BASSI, D.; GIUNCHI, L. Tree efficiency and fruit quality in high-density apple orchards. Acta Horticulturae, The Hague, v.114, p.114-136, 1981.

VAN OOSTEN, H.J Effect of initial tree quality on yield. Acta Horticulturae, The Hague, v.65, p.123-127, 1978.

WALKER, C.D. The development of intensive orchards in England: A historical note. Acta Horticulturae, The Hague, v.114, p.309-317, 1980.

WEBER, M.S. The super spindle system. Acta Horticulturae, The Hague, v.513, p.271-277, 2000.

WEISS, H. Characteristics of the ideal nursery tree and its advantages in the orchard. . Compact Fruit Tree, Tâsmania, v.37, p.23-25, 2004
WERTHEIM, S.J. The training of the slender spindle. Wilhelmindadorp: Pub. Proefstation Fruiteelt, $1968.737 \mathrm{p}$.

WERTHEIM, S.J. Rootstock guide: apple, pear, cherry, european plum. Netherlands: Fruit Research Station, 1998. 144p.

WERTHEIM, S.J.; JOOSSE, M.L. Snoeien van Cox's Orange Pippin na het planten. Fruitteelt, The Hague, v.62, p.166-169, 1972.

WERTHEIM, S.J.; DE JAGER, A.; DUYZENS, M.J.J.P. Comparison of single-row and multi-row planting systems with apple, with regard to productivity, fruit size and color, and light conditions. Acta Horticulturae, The Hague, v.160, p.243-258, 1986.

WUNSCHE, J.N.; LAKSO, A.N.; ROBINSON, T.L.; LENZ, F.; AND DENNING, S.S. The bases of productivity in apple production systems: the role of light interception by different shoot types. Journal of the American Society Horticultural Science, Alexandria, v.121, p.886-893, 1996.

J. Amer. Soc. Hort. Sci. 121:886-893. 